\title{
The Influence of Corporate Governance Mechanisms And Return On Assets On Firm Value
}

\author{
Garin Pratiwi Solihati ${ }^{1}$, Riaty Handayani ${ }^{2}$, Tri Aji Kurniawan ${ }^{3}$ \\ \{garin@mercubuana.ac.id ${ }^{1}$, riaty.handayani@mercubuana.ac.id ${ }^{2}$, ajiqyu@gmail.com ${ }^{3}$ \} \\ Economic and Business Faculty, Mercu Buana University, Jakarta, Indonesia ${ }^{1}$, Economic and \\ Business Faculty, Mercu Buana University, Jakarta, Indonesia ${ }^{2}$, Economic and Business Faculty, Mercu \\ Buana University, Jakarta, Indonesia ${ }^{3}$
}

\begin{abstract}
This study aims to determine the effect of good corporate governance and return on assets on firm value. The object of this research is the consumer goods manufacturing sector listed on the Indonesia Stock Exchange in 2013-2017. This study uses a purposive sampling method that is sourced from the financial report, annual report, and annual closing stock prices of 24 sample companies that meet the requirements to be studied and analyzed using panel data regression with the help of eViews 9 program. The dependent variable in this study is the firm value that is proxied by tobin's q, and the independent variable in this study is good corporate governance that is proxied by institutional ownership, managerial ownership, and the number of audit committee meetings. The results of this study shows that only institutional ownership, managerial ownership, and ROA variables have a significant positive effect on tobin's q, while the variable number of audit committee meetings has a negative effect not significant to tobin's q. This is evidenced from the results of simultaneous tests (Fstatistical tests) and partial test results (t-statistical tests).
\end{abstract}

Keywords: Institutional ownership, Managerial ownership, Number of audit committee meetings, Return on assets, Tobin's q.

\section{Introduction}

High companies value will be followed by high shareholder prosperity (1). The results of a survey conducted by Credit Lyonnais Securities Asia (CLSA) in 2001, showed that good corporate governance has a close relationship with company performance. Keown, et al. (2011) states that the company's goal is to maximize shareholders' wealth, but agency problems can occur when the objectives are implemented (2). Khairiyani et al. (2016) argued that agency problems can be reduced by appropriate monitoring mechanisms, one of which is the corporate governance mechanism (3). However, according to Shinta et al. (2015) the implementation of good corporate governance does not affect stock return and volatility (4).

According to Sutedi (2012), the internal mechanism is influenced by the company's internal factors which include institutional ownership, managerial ownership, independent board of commissioners, and audit committee (5). The existence of institutional investors is considered capable of being an effective monitoring mechanism in every decision taken by managers so that it is not easy to believe in the act of manipulating earnings (Jensen and Meckling, 1976) (6). Institutional investors can apply managerial skills, professional knowledge, and voting rights to influence managers in increasing company efficiency (Lin and 
$\mathrm{Fu}, 2017)$. Jensen and Meckling (1976) also stated that increasing management ownership would reduce agency difficulties through reducing incentives for shareholders and taking over shareholders' wealth (6). This is very potential in reducing unfavorable resource allocation, which in turn will increase the value of the company. Zarkasyi (2008) describes the role of the audit committee as an important pillar in the implementation of good corporate governance (GCG), because the audit committee also plays a role in evaluating financial statements. The financial statements presented by the company become one of the basic considerations for investors to determine the value of a company (7).

Some of the previous studies include the research of Wida and Suartana (2014) (8) and Ratnawati, et al. (2017) which results in institutional ownership having a positive effect on firm value (9). Research conducted by Sofyaningsih and Hardiningsih (2011) states that institutional ownership does not affect company value (10), Rizqia, et al. (2013) stated that managerial ownership has a positive effect on firm value (11). However, Benson and Davidson (2009) (12), Mandaci and Gumus (2010) (13), Zayed (2017) (14), found a negative relationship between managerial ownership and firm value (Tobin's q), and Dah (2016) (15) states that managerial entrenchment is negatively associated with firm value. Research conducted by Brick and Chidambaran (2010) found that board activity (number of annual board meetings and audit committees) had a positive impact on firm value. Onasis and Robin (2016) also found that audit committee meetings had a significant positive effect on firm value (16). However, these findings are different from Soedaryono and Riduifana (2013) which states that audit committee meetings have no significant effect on firm value (17). Research that shows that return on assets affects the value of the company, among others, research conducted by Alghifari, et al. (2013) (18) which states that return on assets (ROA) has a significant effect on firm value [1]. In contrast to these results, research conducted by Hermawan and Maf'ulah (2014) states that return on assets (ROA) does not significantly influence the value of the company (19). Research conducted by rista bintara (2018), found that The interaction between profitability and Good Corporate Governance has a significant and significant effect on Corporate Value with a positive relationship (20).

\section{Literatur Reviews}

\subsection{Agency Theory (Grand Theory)}

Jensen dan Meckling (1976) menyatakan bahwa "We define an agency relationship as a contract under which one or more persons (the principal(s)) engage another person (the agent) to perform some service on their behalf which involves delegating some decision making authority to the agent (6)."

\subsection{Companies Value}

Companies Value is very important because the purpose of financial management is to maximize the value of the company. If the company runs well, then the value of the company will increase or it can be said to maximize stock prices (Weston and Copeland, 1991). One indicator used to measure company value is tobin 'q. This ratio was developed by Professor (James Tobin (1967) (21), if the q ratio is above one, indicating that investment in assets 
produces profits that give a higher value than investment expenditure, this will stimulate new investment. If the ratio is below one-q, investment in assets is not attractive.

\subsection{Good Corporate Governance}

According to the Turnbull Report in the United Kingdom (April 1999) quoted by Tsuguoki Fujinuma, "Corporate Governance is a company's system of internal control that is principally the management of risks that are significant to the fulfillment of its business objectives, with a view to safeguarding the company's assets and over time value of shareholders investments. According to Sutedi (2012), the internal mechanism is influenced by the company's internal factors which include institutional ownership, managerial ownership, independent board of commissioners, and audit committee. Institutional shareholders are corporate shareholders by the government, financial institutions, legal entities, foreign institutions, trust funds and other institutions (5).

Jensen and Meckling (1976) states that company stock ownership by management can equalize the interests of shareholders with the interests of managers so that conflicts of interest between shareholders and managers can be reduced (6). Increasing management ownership will reduce agency difficulties through reducing incentives for shareholders and taking over shareholders' wealth. This is very potential in reducing unfavorable resource allocation, which in turn will increase the value of the company.

According to Collier (1999), the audit committee is a committee that views accounting issues, financial reports and their explanations, internal control systems and independent auditors (22). Audit Committee according to the Financial Services Authority Regulation (POJK) No. 55 / POJK.04 / 2015 holds regular meetings at least 1 (one) time in 3 (three) months.

\subsection{Return on Assets}

Return on Assets is one ratio that shows the company's ability to generate profits from assets used (23). According to Horne \& Machowicz (2012), this ratio measures the overall effectiveness of generating profits through available assets, the power to generate profits from invested capital (24). The higher return on assets shows the better the company's performance, because the funds invested into assets can produce higher earnings after tax (EAT) (Ang, 1997)(25).

\section{Research Model, Hypotesis, and Methodology}

\subsection{Research Population and Samples}

The population used in this study is the Manufacturing Company of the Consumer Goods Industry Sector Registered on the Indonesia Stock Exchange in 2018, which amounts to 43 companies. With several sample selection criteria, there are 24 samples obtained with a fiveyear research year. The total data is 120 data. The sample used in this study used a purposive sampling method.

\subsection{Development of Hypotheses}


H1: Institutional ownership affects the value of the company. , H2: Managerial ownership affects the value of the company. , H3: Number of audit committee meetings influences company value, H4: Return on Assets (ROA) affects the value of the company.

\subsection{Data analysis method}

\section{Descriptive Statistics Analysis}

Methods Data analysis using descriptive statistical analysis used to describe the research variables, without drawing generalizations. The data that has been collected is then tabulated in the table and discussion is carried out descriptively (26). Another method is panel data regression analysis which is a combination of time-series data and cross-sectional data. In this study, researchers conducted data processing using EViews 9 program.

The equation model is as follows:

$$
Y_{i t}=\alpha+\beta 1 X_{i t}+\beta 2 X_{i t}+\beta 3 X_{i t}+\beta 4 X_{i t}+\varepsilon_{i}
$$

Where :

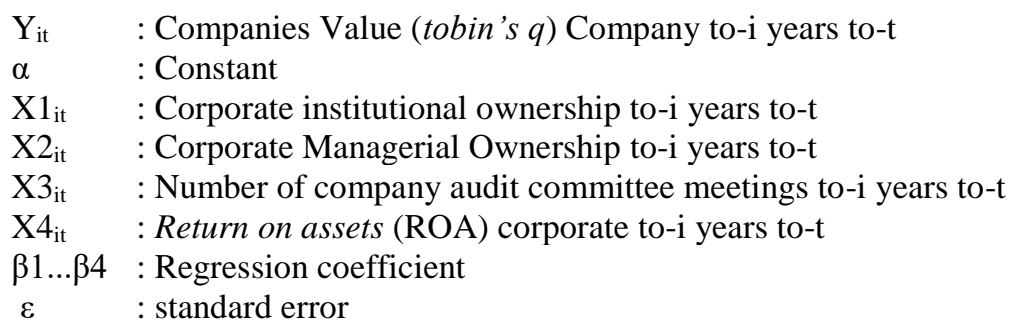

\section{Result and Discussion}

\subsection{Descriptive Statistics Test Results}

Descriptive statistics are used to see an overview of the data used ... The Maximum value is 23.28575 and the minimum value is 0.638239 for Tobisq. The maximum value of tobin's $q$ is due to the large market capitalization value of PT. Unilever Indonesia, Tbk compared with the value of total assets and debt in the company concerned at the end of 2017, while the minimum value of tobin ' $q$ is due to the low market capitalization value of PT. Mayora Indah, Tbk compared with the value of total assets and debt in the company concerned at the end of 2015. The greater the total asset value of a company, the smaller the value of tobin ' $q$ if it is not supported by the value of market capitalization and the emphasis on debt.

The maximum value for $\mathrm{KI}$ is 0.981800 and minimum is 0.051400 . Maximum Value is caused by the large percentage of institutional share ownership in PT. Handjaya Mandala Sampoena, Tbk compared to overall share ownership in the company concerned at the end of 2013, while the minimum value of KI was due to the low percentage of institutional share ownership in PT. Wismilak Intimakmur, Tbk compared with the value of overall share ownership in the company concerned at the end of 2015, 2016, and 2017. The greater the 
institutional ownership, the more power and trust they will have in exercising control and monitoring in controlling the company.

At KM Companies the Maximum Value is 0.38200 and minimum 0.000000. The maximum value of $\mathrm{KM}$ is due to the percentage of managerial share ownership in PT. Wismilak Intimakmur, Tbk compared to overall share ownership in the relevant companies at the end of 2015, 2016, and 2017 while the minimum value of KM was caused by the low percentage of managerial share ownership in several companies in the research sector compared to the value of overall share ownership in companies that concerned in the year of the study. The greater managerial ownership (KM) in this research sector is not dominant (with a maximum value of $38.02 \%$ ) which means that management only acts as an agent or manager responsible to stakeholders in the company.

These results indicate that in general companies in this sector (according to an average of $5,158,333)$ have carried out their activities in accordance with Article 13 of the Financial Services Authority Regulation (POJK) No. 55 / POJK.04 / 2015, namely the Audit Committee holds regular meetings at least 1 (one) time in 3 (three) months. However, based on data collected by the author, there are still several companies that have not followed the existing provisions (as evidenced by the minimum value of 1.000000).

The maximum value of ROA is 0.657201 due to the value of net income after tax PT. Multi Bintang Indonesia, Tbk compared with the total asset value of the company concerned at the end of 2013, while the minimum value of ROA is 0.015386 due to the low value of net income after tax PT. Pyrimad Farma, Tbk compared with the total value of assets in the relevant company at the end of 2014. The greater the total asset value of a company, the smaller the value of ROA if it is not supported by the value of net income after tax.

According to Nachrowi and Usman (2006) (27), as well as Gujarati and Porter (2015) (28), to estimate the model parameters with panel data, there are several techniques / models used, namely: (1) Common Effect / Pooled Least Square (CEM) Method, (2) Fixed Effect (FEM) Method, and (3) Random Effect (REM) Method.

\subsection{Estimation Model Selection Test Results}

\section{F Restricted Test (Chow Test)}

Chow test is a test to determine a fixed effect model or common effect that is more appropriate to be used in estimating panel data. The hypothesis in the chow test is:

$\mathrm{H}_{0} \quad$ : Common effect model , $\mathrm{H}_{1} \quad$ : Fixed effect model

The basis of the rejection of the hypothesis above is that $\mathrm{H} 0$ is rejected if the P-value is smaller than the value of $\alpha$. Conversely, $\mathrm{H} 0$ is accepted if the $\mathrm{P}$-value is greater than the value of $\alpha$. The value of $\alpha$ used is $5 \%$ (26).

F Resticted (Chow Test) Test results show that Cross Section F Probability value is 0.0000 whose value is $<0.05$ so that in this test it can be concluded that the fixed effect model is more appropriate than the common effect model.

\section{Hausman Test}

The next test is the Hausman Test which is a statistical test to choose whether a fixed effect or random effect model is more appropriate to be used in panel data regression. Tests are carried out with the following hypothesis:

$\mathrm{H}_{0} \quad$ : Random effect model, $\mathrm{H}_{1} \quad$ : Fixed effect model

If Hausman statistic value is greater than its critical value, $\mathrm{HO}$ is rejected and the right model is a fixed effect model, whereas conversely if Hausman statistical value is smaller than 
its critical value, the right model is a random effect model, or in other words, $\mathrm{H} 0$ is rejected if $\mathrm{P}$ - value smaller than $\alpha$. Conversely, $\mathrm{H} 0$ is accepted if the $\mathrm{P}$-value is greater than the value of $\alpha$. The value of $\alpha$ used is $5 \%$ (26).

The Hausman Test results show that the random cross section probability value is 0.0000 with a value of $<0.05$ so that it can be concluded that the fixed effect model is more appropriate than the random effect model in this study.

\section{Uji Lagrange Multiplier (LM)}

It is a test to find out whether a random effect model or a common effect model is more appropriate to use. In this study, a Lagrange Multiplier (LM) Test is not necessary.

With the Generalized Least Square (GLS) / Weights Least Square method, it is done to minimize the existence of classic assumptions so that the results can be compared. Based on these explanations, the following is the weights / EGLS fixed effect model output on the eViews 9 program: From the results obtained coefficients for C-2.547614, KI 7.325696, KM 9.904573, RKA -0.026010, ROA 7.199709, Adjusted R- squared is 0.949328, Prob (Fstatistic) 0.000000 , Durbin-Watson stat 1.850383 .

The results of the comparison between the two panel regressions. Following are the results of the comparison of the two fixed effect models (FEM vs. EGLS):

Table 1. EGLS Panel vs. FEM Panel Test Results Source: eViews 9

\begin{tabular}{|l|l|l|}
\hline \multicolumn{2}{|l|}{ FEM vs EGLS } \\
\hline Parameter & FEM & EGLS \\
\hline $\begin{array}{l}\text { Adjusted } \\
\text { squared }\end{array}$ & 0.952585 & 0.949328 \\
\hline Prob (F-statistic) & 0.000000 & 0.000000 \\
\hline Prob (T-statistic) & 1 variabel < 0.05, 4 lainnya >0.05 & $\begin{array}{l}3 \text { variabel }<0.05,2 \text { lainnya > } \\
0.05\end{array}$ \\
\hline Durbin Watson & 1.382266 & 1.850383 \\
\hline
\end{tabular}

Based on the comparison of results according to table 9, it is evident that the EGLS panel model is the best model used in this study, so the panel data regression equation used in this study is as follows:

$\mathrm{Y}_{\text {it }}$

$$
=\alpha+\beta 1 X_{i t}+\beta 2 X_{i t}+\beta 3 X_{i t}+\beta 4 X_{i t}+\varepsilon_{i t}
$$
Tobin's $Q=-2.547614+7.325696 . \mathrm{KI}+9.904573 . \mathrm{KM}-\mathbf{0 . 0 2 6 0 1 0 . R K A}+$
7.199709.ROA $+\varepsilon$

Where:

$\mathrm{KI}=$ Institutional ownership, $\mathrm{KM}=$ Managerial ownership, RKA = Number of company audit committee meetings, ROA $=$ Return on Assets, $\varepsilon=$ Standard error

The results of the panel data regression equation indicate that institutional ownership, managerial ownership, and return on assets (ROA) variables have a positive coefficient, but the number of audit committee meetings has a negative coefficient. This means that an increase in the number of institutional ownership, managerial ownership, and return on assets 
(ROA) will increase the value of the company (tobin's q), while the number of audit committee meetings does not increase the value of the company (tobin's q).

\subsection{Hypothesis Test Results}

1. Determination Coefficient Test (R2)

Based on the test results it is known that the results of the adjusted R2 of the independent variables in this study are 0.949328 or $94.93 \%$. This means that $94.93 \%$ of company value (tobin 'q) is influenced and can be explained by the four independent variables.

\section{F-statistic test}

The $\mathrm{F}$ statistic value and probability $\mathrm{F}$ statistic value in this study according to the regression that has been done is 83.57221 with a probability of 0.000000 . The value of $F$ table can be seen in the table F statistic (F count) on df $1=$ number of variables- 1 or $5-1=4$ and df $2=$ nk-1 or $120-4-1=115$ ( $\mathrm{k}=$ number of independent variables), with a significance of 0.05 obtained the results of $\mathrm{F}$ table $=2.45$, so that F-count $>$ F-table is 83.57221> 2.45 which means Ho is rejected. The probability value of the F statistic is also smaller than the significant value $\alpha=5 \%$, it can be concluded that $\mathrm{H} 0$ is rejected. Thus, the independent variables in this study, namely institutional ownership, managerial ownership, the number of audit committee meetings, and return on assets jointly / simultaneously have a positive and significant effect on the dependent variable tobin's q.

\section{T-statistical test}

The value of $\mathrm{t}$ table can be seen in the table $\mathrm{t}$ statistics at $\mathrm{df}=\mathrm{nk}-1$ or $120-4-1=115(\mathrm{k}$ is the number of independent variables), with a significance of 0.05 and the two-sided test results obtained t table $=1.98081 /-1,98081$.

\section{Institutional Ownership}

The value of t-Statistic obtained from institutional ownership variables in this study is 2.489060 with a probability value of 0.0146 . The value of $t$-statistic $>t$-table $(2.489060>$ 1.98081) which means $\mathrm{H} 0$ is rejected and $\mathrm{H} 1$ is accepted, and the probability value shows 0.0146 which means it is smaller than the significance value of $0.05(5 \%)$, it can be concluded that the institutional ownership variable is partially significant positive effect on firm value variables (Tobin's Q).

5. Managerial ownership

The value of t-Statistic obtained from managerial ownership variables in this study is 2.880619 with a probability value of 0.0049 . The value of $t$-statistic $>$ t-table $(2.880619>$ 1.98081) which means $\mathrm{H} 0$ is rejected and $\mathrm{H} 1$ is accepted, and the probability value shows 0.0049 which means smaller than the significance value of $0.05(5 \%)$, it can be concluded that the managerial ownership variable is partially significant positive effect on firm value variables (Tobin's Q).

\section{Number of Audit Committee Meetings}

The value of t-Statistic obtained from the variable number of audit committee meetings in this study is -0.969383 with a probability value of 0.3349 . The value of t-statistic $>t$-table ($0.969383<1.98081$ ) which means that $\mathrm{H} 0$ is accepted and $\mathrm{H} 1$ is rejected, and the probability value shows 0.3349 which means greater than the significance value of $0.05(5 \%)$, it can be 
concluded that the variable number of committee meetings partially auditing negatively has no significant effect on firm value variables (Tobin's Q).

\section{Return on Assets}

The value of t-Statistic obtained from the return on assets variable in this study is 5.788977 with a probability value of 0.0000 . The value of $t$-statistic $>t$-table $(5.788977>$ 1.98081) which means that $\mathrm{H} 0$ is rejected and $\mathrm{H} 1$ is accepted, and the probability value shows 0.0000 which means that it is smaller than the significance value of $0.05(5 \%)$, it can be concluded that the return on assets variable partial has positive significant effect on firm value variable (Tobin's q).

\subsection{Discussion of Research Results}

1. The effect of Institutional Ownership on Company Values shows that institutional ownership variables have an influence on firm value, it is concluded that the first hypothesis is accepted. The greater the percentage of institutional ownership in a company, the greater the trust and interest of the community and investors towards the company, so that the impact on the value of the company increases.

2. The Effect of Managerial Ownership on Company Values shows that managerial ownership variables have an influence on firm value, it is concluded that the second hypothesis is accepted. The greater the percentage of managerial ownership in a company, the higher the value of the company concerned, which of course must be supported by the competence and professionalism of the management and commissioners of the company in managing and carrying out the mandate given by stakeholders.

3. Effect of the Number of Audit Committee Meetings on Company Values shows the variable number of audit committee meetings has no influence on company value, it is concluded that the third hypothesis is rejected. The more number of audit committee meetings, will not have an impact on increasing the value of the company. This can be caused by the results of meetings conducted by the audit committee not always being a reference for the board of commissioners and management in conducting company planning and evaluation, or the existence of other more relevant variables that are more influential related to the activities of the audit committee, namely among the committee members audit, independence of members, audit committee reports to commissioners, and meetings with external auditors.

4. Effect of Return on Assets on Company Values The results of the t-test show that the variable return on assets (ROA) has an influence on firm value, concluded that the fourth hypothesis is accepted. Return on assets (ROA) has a significant positive effect on firm value (tobin's q). The higher the ROA value of a company, the better the company's ability to manage its assets so that the value of the company is expected to increase. This value can also be measured by comparing the value of ROA in similar companies in the same sector.

\section{Conclusion}

This study aims to determine the effect of good corporate governance and profitability on the value of the company in the consumer goods manufacturing sector listed on the Indonesia 
Stock Exchange in 2013-2017. Good corporate governance is proxied by institutional ownership, managerial ownership, and the number of audit committee meetings, profitability is proxied by return on assets, and company value is proxied by tobin's q. Based on the results of hypothesis testing and data analysis of the discussion that has been conducted, conclusions can be obtained, among others, institutional ownership shows that it has a significant influence on the value of the company with a positive direction. This shows that the greater the number of institutional ownership, the higher the value of the company. Managerial ownership shows that it has a significant influence on firm value in a positive direction. This shows that the greater the number of managerial ownership, the higher the value of the company. The number of audit committee meetings shows that it does not have a significant effect on the value of the company with negative direction. This can be interpreted how much the frequency of the audit committee holds a meeting within the company within one year, it will not affect the increase / decrease in the value of the company, it will even tend to show opposite results, although not significant. Return on assets (ROA) shows that it has a significant effect on firm value in a positive direction. This shows that any increase in net profit after tax on total assets in the company within a period of 1 year will have an impact on the increase in the value of the company.

\section{References}

1. Brigham EF, Gapenski LC. Intermediate Financial Management. Fifth Edition.Orlando: The DrydenPress. 1996.

2. Keown AJ, Scott DF, Martin JD, Petty JW. Manajemen Keuangan: Prinsip Dan Penerapan Jilid 1 Edisi 10." Jakarta: PT. Indeks. 2011.

3. RAHAYU S, HERAWATY N. Pengaruh Struktur Kepemilikan dan Struktur Pengelolaan Terhadap Kinerja Keuangan Serta Implikasinya Terhadap Nilai Perusahaan pada Perusahaan LQ 45 di Bursa Efek Indonesia Tahun 2012-2014. 2016;

4. Melzatia S, Rahayu S, Infriawati F. Analisis Pengaruh Implementasi Good Corporate Governance Terhadap Return dan Volatilitas Saham. J Profita. 2015;7(1).

5. Sutedi A. Good corporate governance. Sinar Grafika. 2011.

6. Zinman J, Karlan D, Young J, West A, Weill L, Godlewski CJ, et al. Observing Unobservables: Identifying Information Asymmetries With a Consumer Credit Field Experiment. Econometrica [Internet]. 2009;4(3):1993-2008. Available from: http://www.eurojournals.com/MEFE.htm\%0Ahttp://www.jstor.org/stable/1879431\%0 Ahttp://about.jstor.org/terms\%0Ahttp://link.springer.com/chapter/10.1007/978-1-34924002-

9_9\%5Cnhttp://qje.oxfordjournals.org/lookup/doi/10.2307/1879431\%0Ahttp://www.c rimbbd.org/w

7. Zarkasyi W. Good corporate governance pada badan usaha manufaktur, perbankan, dan jasa keuangan lainnya." Bandung: Alfabeta. 2008.

8. Damayanti NPWP, Suartana IW. Wayan Suartana. "Pengaruh Kepemilikan Manajerial dan Kepemilikan Institusional pada Nilai Perusahaan. E-Jurnal Akunt. 2014;575-590.

9. Ratnawati V, Freddy D, Wahyuni N. The Impact of Institutional Ownership and a Firm's Size on Firm Value: Tax Avoidance as a Moderating Variable. 2018;

10. Sofyaningsih S, Hardiningsih P. Struktur kepemilikan, kebijakan dividen, kebijakan utang dan nilai perusahaan. Din Keuang dan Perbank. 2011;3(1):68-87. 
11. Rizqia DA, Sumiati SA. Effect of Managerial Ownership, Financial Leverage, Profitability, Firm Size, and Investment Opportunity on Dividend Policy and Firm Value. Res J Financ Accounting2. 2013;4(11):120-30.

12. Benson BW, III WND. Reexamining the managerial ownership effect on firm value. J Corp Financ. 2009;15(5):573-86.

13. Mandacı P, Gumus G. Ownership concentration, managerial ownership and firm performance: Evidence from Turkey. South East Eur J Econ Bus. 2010;5(1):57-66.

14. Almostafa $\mathrm{Z}$ and. Corporate Governance and Financial Firm Performance: Evidences from Jordan. Res J Financ Account. 2017;4(11).

15. Dah MA. Governance and firm value: The effect of a recession. Res Int Bus Financ [Internet]. 2016;37:464-76. Available from: http://dx.doi.org/10.1016/j.ribaf.2016.01.013

16. Onasis K, Robin R. Pengaruh tata kelola perusahaan terhadap nilai perusahaan pada perusahaan sektor keuangan yang terdaftar di BEI. Bina Ekon. 2016;20(1):1-22.

17. Soedaryono B, Riduifana D. Pengaruh Good Corporate Governance Terhadap Nilai Perusahaan Melalui Corporate Social Responsibility. Media Ris Akuntansi, Audit Inf. 2017;13(1):1-34.

18. Alghifari S, Triharjono S, Juhaeni Y. Effect of return on assets (roa) against Tobin's q: Studies in food and beverage company in Indonesia stock exchange years 2007-2011. Int J Sci Res. 2013;2:108-16.

19. Hermawan S, Nurul A. Pengaruh Kinerja Keuangan Terhadap Nilai Perusahaan Dengan Pengungkapan Corporate Social Responsibility Sebagai Variabel Pemoderasi. J Din Akunt. 2014;6(2):103-18.

20. Bintara R. Pengaruh Profitabilitas, Growth Opportunity, dan Struktur Modal terhadap Nilai Perusahaan dengan Good Corporate Governance sebagai Variabel Pemoderasi (Studi Empiris pada Perusahaan Manufaktur yang Terdaftar di Bursa Efek Indonesia Tahun 2012-2015). Profita. 2018;11(2):306-28.

21. Tobin J. The neutrality of money in growth models: a comment. Economica. 1967;6972.

22. Collier P, Gregory A. Audit committee activity and agency costs. J Account Public Policy. 1999;18(4):311-32.

23. Sartono A. Manajemen Keuangan teori dan Aplikasi edisi 4." Yogyakarta: BPFE. 2001.

24. Horne JC Van, Jr JMW. Prinsip-prinsip Manajemen Keuangan Fundamentals of Financial Management." Edisi Ketiga Belas. Buku Kedua.. Jakarta: Penerbit Salemba Empat. 2012.

25. Ang R. Buku pintar pasar modal Indonesia. 1997.

26. Wati LN. Metodologi Penelitian Terapan, Aplikasi SPSS, EVIEWS, Smart PLS dan Amos. Bandung. 2017.

27. Nachrowi D, Usman. Penggunaan Teknik Ekonometrika. Jakarta: Raja Grafindo Persada. 2006.

28. Gujarati DN, Porter DC. Dasar-Dasar Ekonometrika, Edisi 5." Jakarta: Salemba Empat. 2012. 